\title{
Forord til Kasus, sætningsled og semantiske roller
}

\author{
STEN VIKNER \\ Afdeling for Engelsk, Aarhus Universitet, Danmark \\ VOLKMAR ENGERER \\ Statsbiblioteket, Danmark
}

Dette nummer af Tidsskrift for Sprogforskning præsenterer fire af bidragene til det Sjette Forskningskollokvium Sprog på Statsbiblioteket, som fandt sted den 24 . november 2005. Temaet for kollokviet og dermed for dette nummer af Tidsskrift for Sprogforskning er "Kasus, sætningsled og semantiske roller".

Lad os tage som konkret eksempel den følgende tyske sætning:

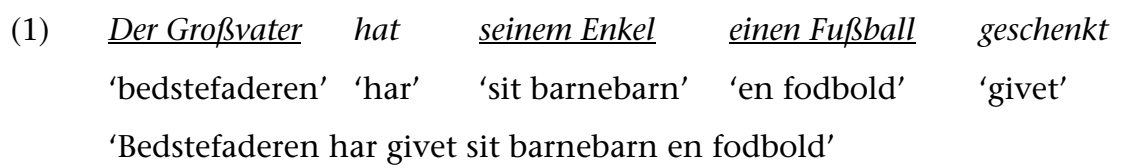

De understregede ordgrupper er de tre nominalled, bedstefaderen, sit barnebarn og en fodbold og de kan bruges til at illustrere forskellene og lighederne mellem kasus, sætningsled og semantiske roller.

Hvis vi beskriver nominalleddene i vores eksempel med hensyn til kasus, ser resultatet således $\mathrm{ud}$ :

$\begin{array}{llll}\text { (2) DerGroßvater } & \text { hat } & \underline{\text { seinem Enkel }} & \text { einen Fußball } \\ \text { NOMINATIV } & & \text { DATIV } & \text { AKKUSATIV }\end{array}$

Betegnelsen casus er den latinske oversættelse af det oldgræske ptōsis (begge betyder 'fald', som også er den oprindelige danske betegnelse for kasus, hvor nævnefald, genstandsfald, hensynsfald og ejefald betyder henholdsvis nominativ, akkusativ, dativ og genitiv). Kasusbegrebet går tilbage til den græske 
filosofiske skole stoikerne i 2. og 1. årh. f. Kr. Ifølge Wackernagel (1926: 15) er ideen at grundformen er som en opretstående stok og de andre kasusformer "falder" væk fra grundformen:

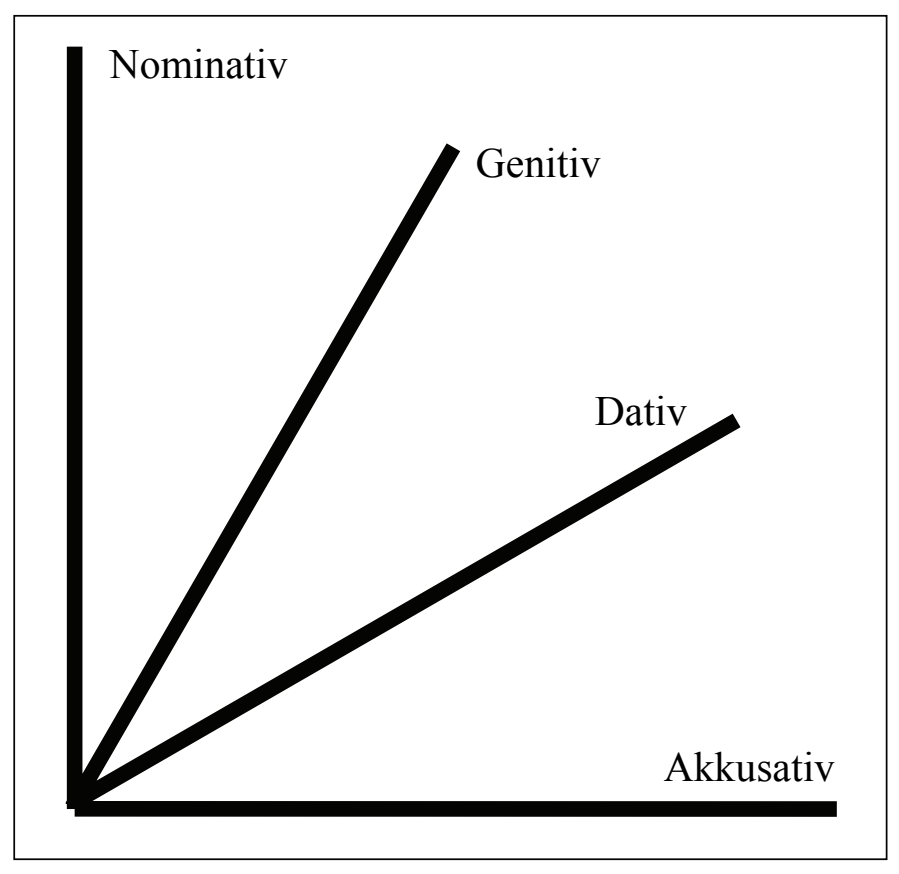

Herfra kommer så ifølge Meier-Brügger et al. (2002: XVII) forskellen mellem den opretstående kasus nominativ ("casus rectus") og de andre kasus, som er oblikke, dvs. skæve ("casus obliqui"). Et andet bud på oprindelsen af begrebet kasus er at de forskellige former af nominalet svarer til de forskellige måder en terning kan falde på (Krahe 1970: 110, Seuren 1998: 20, fn. 4).

Kasus er altså oprindelig en morfologisk betegnelse for forskellen mellem substantivets forskellige former. I de tilfælde hvor der ikke findes forskellige kasus i et paradigme (som f.eks. i danske substantiver), er det nærliggende at sige at kasus slet ikke findes. Dette er dog ikke den eneste mulighed, idet man også kan vælge at gå ud fra at alle nominalled på dansk bliver tilskrevet kasus (ligesom alle nominalled på tysk). Om denne abstrakte (eller usynlige) kasus så er nominativ eller akkusativ, kan konstateres ved at substituere nominalledet med et af de pronominer hvor der er forskel mellem nominativ og akkusativ, f.eks. de vs. dem. 
Hvis vi forlader kasus og i stedet beskriver nominalleddene i vores eksempel efter hvilke sætningsled de udgør, ser resultatet således ud:

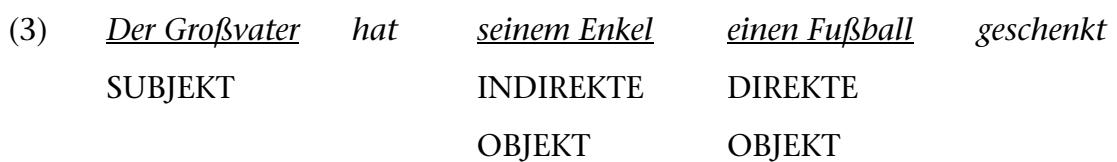

Det mest fremtrædende sætningsled er subjektet (fra oldgræsk hypokeímenon, begge betyder 'det underliggende' eller 'det tilgrundliggende'), og det går tilbage til Aristoteles, hvor det dog betegner det emne der tales om. Først hos Ammonius i det 5. århundrede bliver subjekt brugt specifikt om det sproglige udtryk for det der tales om, hvilket er begyndelsen på distinktionen mellem subjekt og prædikat (Seuren 1998: 122). Sætningsledsbetydningen af betegnelsen "subjekt" og distinktionen mellem de forskellige sætningsled (altså subjekt i modsætning til f.eks. objekt og indirekte objekt) er dog af langt nyere dato, og findes først hos franskmanden Gabriel Girard i 1747 (Burkhard 2003) og hos danskeren Jens Pedersen Høysgaard i 1752 (Høysgaard 1752: 64, § 709ff).

Sætningsled bliver også kaldt "grammatiske relationer" eller "syntaktiske funktioner", idet de antages at beskrive en bestemt funktion i sætningen, altså f.eks. det at være sætningens subjekt.

Endelig, hvis vi undersøger nominalleddene i vores eksempel med hensyn til semantiske roller, ser resultatet således ud:

$\begin{array}{llll}\text { (4) DerGroßvater } & \text { hat seinem Enkel } & \text { einen Fußball } & \text { geschenkt } \\ \text { AGENS } & \text { RECIPIENT } & \text { TEMA }\end{array}$

Mens sætningsleddene udelukkende betegner forholdet mellem de sproglige udtryk, henviser de semantiske roller (som ofte også kaldes "tematiske relationer") også til forholdet mellem de entiteter som de sproglige udtryk refererer til, her altså at bedstefaderen har udført en handling, at hans barnebarn har modtaget et eller andet, og at der er sket noget med en fodbold.

Selvom semantiske roller i en vis forstand går helt tilbage til Pānini og også findes hos englænderen Frank Blake i 1930 (Dowty 1991: 548), så får de først 
deres nuværende form i midten af 1960erne, hos Gruber (1965) og i Fillmores kasusgrammatik (Fillmore 1966), hvor de kaldes dybdekasus ("deep case").

Kasus, sætningsled og semantiske roller har altså det til fælles at de alle tre bruges til at beskrive et nominalled og dets relation til resten af den sætning det forekommer i. Forskellene er, stærkt forenklet, at disse nominalled anskues fra tre forskellige synsvinkler, en morfologisk (kasus), en syntaktisk (sætningsled) og en semantisk (semantiske roller). Som det også vil fremgå af bidragene i dette nummer af Tidsskrift for Sprogforskning, hersker der langtfra fuldstændig enighed om hvor store forskellene mellem disse synsvinkler er, og om man virkelig har brug for dem alle tre, eller om en eller måske endda to af dem kan undværes.

Vi kommer nu til de enkelte bidrag. Det første bidrag med titlen "Satzglieder, Kasus und semantische Rollen: eine Einführung" er resultatet af et tysk-dansk samarbejde mellem Eva Engels og Sten Vikner, begge Institut for Sprog, Litteratur og Kultur, Aarhus Universitet. Bidraget er - som titlen antyder - en introduktion til emnet. Engels og Vikner har, ligesom de andre bidragydere i denne sektion, taget kollokviets (og dette nummers) titel "Kasus, sætningsled og semantiske roller" alvorligt, idet de fortolker konjunktionen af navnene på disse tre størrelser som en pragmatisk induceret påstand om, at der skulle være en mere end tilfældig sammenhæng mellem de beskrevne fænomener (for at vælge den nok mest forsigtige - og mindst prætentiøse formulering). Denne svagt formulerede version vil de gerne gå med til (se "[die Relationen von Satzglied, Kasus und semantischer Rolle stehen] aber auch nicht in einem völlig willkürlichen Zusammenhang [...]", Engels/Vikner, afsnit 2), men ikke mere end det: En vigtig, hvis ikke den vigtigste, pointe i Engels' og Vikners bidrag er, systematisk at synliggøre den relative uafhængighed mellem de tre lag.

Og denne "uafhængighedstese" argumenterer de for ved hjælp af en korrelativ metode ("det, der ikke hele tiden har hinanden i hånden, hører heller ikke rigtigt sammen" kunne være deres motto). Den korrelative metode hviler på et bæredygtigt empirisk grundlag med eksempler fra bl.a. dansk og tysk, men også fra et ikke-germansk (ikke-indoeuropæisk) sprog, nemlig finsk. Sammenhængen mellem sætningsled, morfologisk kasus og semantisk rolle anskues som ikke signifikant - i den forstand, at der fra tilstedeværelsen af en værdi på ét niveau, fx objekt på sætningsledsniveau, ikke pr. automatik kan afledes en lignende 
tilstedeværelse af andre værdier på de øvrige niveauer (fx akkusativ på kasusniveau eller tema inden for de semantiske roller).

Efter at have introduceret begreberne sætningsled (Satzglied), kasus og semantisk rolle, analyserer Engels og Vikner kasus, hvor funktionen formalt er at signalere et bestemt sætningsled, og dermed, på en indirekte måde, at hjælpe med til at fastlægge aktantens semantiske rolle (se "die Kasusdistinktionen [...] ermöglichen somit, über die Satzgliedfunktion $\mathrm{zu}$ erschliessen, welche der semantischen Rollen [...] die Argumente jeweils übernehmen", Engels/Vikner, afsnit 2.1).

Kasussynkretismer kan, som Engels og Vikner viser, bidrage til tvetydigheder på sætningsledsplan (Hvad er subjekt, hvad er objekt?) og på denne måde bytte rundt på semantiske roller (Har hunden bidt postbudet eller omvendt?!). Hertil må siges, at netop disse eksempler til en vis grad kan understøtte antagelsen om, at der eksisterer et vist korrelativt forhold mellem kasus og sætningsled på den ene side og sætningsled og semantisk rolle på den anden side. For det første afspejler en homomorf ambiguitet på sætningsledsniveau ambiguitet på kasusplan, fx en nominativ-akkusativ-synkretisme, hvor tvetydigheden netop ikke er tilfældig, men består af de sætningsled, der korrelativt-defaultmæssigt er koblet til de tilsvarende kasus - i tilfældet her til subjekt og objekt (ikke overraskende er andre sætningsledstyper som adverbial eller indirekte objekt udelukket).

For det andet er koblingen sætningsled-semantisk rolle heller ikke tilfældig i flertydige kontekster, hvilket fremgår af Engels' og Vikners eksempler. Er der foretaget én tilordningsmulighed med kasus-sætningsled i en tvetydig konstruktion, fx das Pferd/NOM/Subj in Das Pferd beisst die Frau, sml. eks. (12) i Engels/Vikner, så falder valget af semantisk rolle utvetydigt på agens. Alt i alt kan ambige kontekster og kasussynkretismer, som det er fremført i Engels' og Vikners bidrag, fortolkes som eksempler på et eksisterende og påviseligt forhold mellem kasus, sætningsled og semantisk rolle. ${ }^{1}$

Hovedparten af Engels' og Vikners bidrag er en detaljeret og systematisk påvisning af, at kasus, sætningsled og semantisk rolle ikke korrelerer præcist, altså varierer uafhængigt af hinanden. Forfatterne påviser med et eksempel på 
brug af passiv, at der er store forskelle på, hvordan og med hvilke verber argumenterne nyfordeles ved passivering mellem de germanske sprog indbyrdes (herunder også islandsk). Afslutningen af Engels' og Vikners bidrag er en analyse af det finske kasussystem, hvor de viser, at der ikke engang i dette kasusmæssigt veludbyggede sprog findes et én-til-én-korrespondance mellem kasus, sætningsled og semantisk rolle.

I det andet bidrag behandler Hans Götzsche, Institut for Kommunikation, Aalborg Universitet, "Sætningsled, kasus og signifikation". Ligesom Engels og Vikner ser han kollokviets emne "Kasus, sætningsled og semantiske roller" som en "bunden opgave", idet "[...] man sammensætter vel et emne, fordi man mener, at der er en eller anden forbindelse mellem de indgående begreber" (Götzsche, afsnit 1), hvilket han har helt ret i. Götzsche er først og fremmest skeptisk over for semantiske roller, som, da de ikke er observerbare størrelser, kun kan omtales inden for rammerne af en sprogteori.

I det følgende fremlægger Götzsche principperne for en teori, som han og hans kolleger i Aalborg har udviklet - "Formative Grammar" og den tilhørende tegnmodel. Sætningsled har, i modsætning til semantiske roller, en fast plads i Formative Grammar. De er "grundlæggende størrelser" og "udtryk for et begreb" (Götzsche, afsnit 2). Sætningsled, som "[...] skal vise hvem der er hvad [...]" (Götzsche, afsnit 2), er del af et teoretisk lag i Formative Grammar, også kaldet "syntaktisk signifikation". Syntaktisk signifikation udfører sin opgave ved hjælp af topologiske (ordstillingsmæssige) eller morfologiske midler, herunder kasusformer. Dermed, mener vi, følger Götzsche tesen om et funktionelt forhold mellem kasus og sætningsled, som tillægger kasus den funktion (eller "opgave") at vise, hvilket sætningsled, der foreligger, og på den måde bidrage til sætningens (korrekte) interpretation. Denne tese kommer også til syne i Engels' og Vikners bidrag, blot med den forskel, at den funktionelle kæde på en transitiv måde forlænges til semantiske roller hos sidstnævnte. Det vil Götzsche ikke være med til.

Semantiske roller er ikke mulige at iagttage, men det gælder nok de fleste af de lingvistiske enheder ("[...] man kan ikke slutte fra det forhold, at noget ikke er observeret til, at det ikke findes [...]", Götzsche, afsnit 3). Götzsche vender sig endvidere imod, at der "[...] altid [!] genspejler sig en rollefordeling [...]" 
(Götzsche, afsnit 3) i kasusbrug (hans eksempel er dativen, se i den sammenhæng også Kratschmers bidrag). Her kan der måske anes en hentydning ikke kun til den grundlæggende antagelse hos tilhængere af kasusgrammatikken, men også til den tyske gren af "indholdsrelateret grammatik" (inhaltsbezogene Grammatik), hvor man bestræber sig på at etablere faste kasusbetydninger i sprogets kasussystem. Alt i alt kan der ifølge Götzsche i sidste ende ikke skelnes mellem semantiske roller og udtrykskategorier som fx kasus. De betegner det samme - eller sagt på en anden måde: kasus som formalt og sanseligt fænomen eksisterer, men det gør semantiske (eller tematiske) roller ikke. Götzsche afviser også af videnskabsteoretiske grunde eksistensen af semantiske roller, da de ikke, uden at komme i både teoriinterne og erkendelsesteoretiske problemer, kan inkorporeres i videnskabelige teorier, dvs. teorier, der kan falsificeres.

At semantiske roller i en vis forstand "eksisterer" for lingvisten skyldes ifølge Götzsche den "ontologiske fejltagelse", at der fra eksistensen af en sproglig term (fx den danske ordforbindelse semantisk rolle) med en betydning (beskrivelsen, som findes fx i lingvistiske opslagsbøger og der er konkurrence om i den pågældende faglitteratur) sluttes til eksistensen af en ting, der bærer dette navn og gør beskrivelsen sand. I denne sammenhæng kritiserer Götzsche Van Valins håndbogsartikel om "Functional Relations" (Van Valin Jr. 1999: 150), hvor Van Valin underbygger vigtigheden af semantiske roller gennem deres empiriske relevans, nemlig at sætte elementer (her: participanter) i hændelsesstrukturen og deres sproglige kodering i forhold til hinanden (se hertil også den skarpe kritik af Kristensen i dette bind, hvor hun påpeger, at semantiske roller udelukkende er knyttet til den specielle aktantmodel, udtrykt i den enkelte sætnings scenarium, og på ingen måde peger ud over denne model).

Det følgende bidrag stammer fra Susanne Annikki Kristensen, Institut for Kommunikation, Aalborg Universitet. Også Kristensen tager, ligesom Engels/Vikner og Götzsche tidligere, den pragmatiske implikatur om en dybere sammenhæng mellem kollokviets centrale størrelser kasus, sætningsled og semantiske roller (og den medfølgende eksistenspræsupposition angående semantiske roller!) til sig. Kristensen tilbød os i første omgang sit manuskript med titlen "Om hvorfor kollokviets titel bør revideres". Kristensen arbejder også inden for Götzsches tradition omkring Formative Grammar og stiller sig, ligesom Götzsche, skeptisk over for semantiske roller - dog ikke så radikalt som Götzsche 
gør ("[...] semantiske roller [er] ikke [...] nødvendige størrelser i en sproglig beskrivelse", Kristensen, afsnit 1).

Kristensen indleder med en behandling af kasusbegrebet $i$ forskellige sammenhænge og vender sig først og fremmest imod den traditionelle tendens til at sætte kasus (form) lig med syntaktisk funktion (sætningsled). Kristensen påpeger, at denne tendens til at identificere kasus med sætningsled ("en-til-enkorrespondance mellem form og funktion", Kristensen, afsnit 2) har fået forskellige negative konsekvenser for den grammatiske analyse, herunder en nedprioritering af syntaktisk arbejde, da syntaksen så at sige allerede er indbefattet i de morfologiske former. En anden konsekvens er det, efter hendes mening, uheldige forsøg på at hypostasere kasusbetydninger samt, at det latinske kasussystem stadigvæk står som forbillede for den moderne sproganalyse ("imperialistiske tendenser", Kristensen, afsnit 2).

En konsekvens af Kristensens syn på kasus og forholdet til syntaksen er, at man må "[...] tage udgangspunkt i syntaksen og derefter [...] morfologien frem for omvendt, idet man ud fra en morfologisk form ikke automatisk kan udlede den syntaktiske funktion" (Kristensen, afsnit 3). Efter at have kritiseret de traditionelle blandede semantiske og morfologiske sætningsledsbestemmelser, diskuterer Kristensen grammatiske tilgange, der rent syntaktisk-strukturelt bestemmer sætningens relationale elementer, her først og fremmest subjekter og objekter. En sådan tilgang er Chomskys generative teori, hvor subjekt- og objektfunktioner kendetegnes ved faste syntaktiske positioner i et X-bar-træ. Kristensen kritiserer i denne sammenhæng den dominerende rolle, som ord- og ledfølge indtager og som karakteriserer X-bar-teorien og teorien fremlagt i det Minimalistiske Program med dens overflødighedshorn af (ofte) usynlige flytninger for at give den korrekte konstituentrækkefølge. Hun anser ikke denne "lineariserende" tilgang til syntaksen som optimal for en beskrivelse af morfologiske sprog som latin eller finsk. Den anden generative teori, som diskuteres i Kristensens bidrag, er Lexical Functional Grammar (LFG) i Bresnans version (sml. Bresnan 2001).

I forbindelse med semantiske roller mener Kristensen, at deres hovedfunktion er at konstituere det scenarium, som udtrykkes i sætningen (Kristensen, afsnit 4). Og, da der ikke ligger noget udenfor dette scenarium, der kan fæstnes til disse 
roller, er problemet, “[...] at man som teoretiker nødvendigvis må forstå sætningen, før man kan analysere sig frem til, hvilke af sætningens størrelser, der udgør hvilke semantiske roller [...]" (Kristensen, afsnit 4). Endvidere kritiserer Kristensen den udbredte praksis hos kasusteoretikere, at de introducerer ad-hoc-roller i deres analyser. Kristensen mener ikke, at semantiske roller er nødvendige, “[...] hvis man ellers arbejder med en konsistent syntaktisk teori [...]" (Kristensen, afsnit 4). I resten af Kristensens bidrag fremlægges denne teori (uden semantiske roller), som kaldes Epi-Formale Syntaksteorie $(\operatorname{EFA}(\mathrm{X}))$. Teorien stammer oprindeligt fra Hans Götzsche (se Götzsches bidrag og litteraturhenvisninger $\mathrm{i}$ dette bind) og svarer til det han kalder "Formative Grammar".

Det sidste bidrag i denne tematiske sektion om "Kasus, sætningsled og semantiske roller" har den meget sigende tyske titel "Der verflixte italienische Dativ - ein (erster) semantisch-grammatikalischer Zähmungsversuch" og er skrevet af romanisten Alexandra Kratschmer, Institut for Sprog, Litteratur og Kultur, Aarhus Universitet. Kratschmer tematiserer ikke eksplicit spørgsmålet om eksistensen af tematiske roller - som det var tilfældet i de forudgående bidrag. Kratschmer vælger i stedet at lade selve den sproglige analyse påvise semantiske roller som nyttige størrelser. Det har i lingvistikken altid været et godt argument for at bibeholde analytiske entiteter - på trods af deres måske tvivlsomme status set fra et fagteoretisk og videnskabsteoretisk synspunkt.

Kratschmer indleder med en diskussion af kasusbegrebet dativ i italiensk og fremhæver i denne sammenhæng fordele ved en semantisk eksplikation af termen "dativisk": Hun betragter begrebet "dativisk" som en præteoretisk semantisk term, som danner et overbegreb for en gruppe semantiske roller og som i princippet er uafhængige af nominalgruppernes kasusmarkeringer, her især dativ (som kasus) (Kratschmer, afsnit 1). Man lægger mærke til, at Aalborgskolens (sml. Götzsches og Kristensens bidrag i dette bind) forsøg på at identificere kasus med betydning ville blive afvist, hvilket kan have noget at gøre med det sprogteoretisk-universalgrammatiske perspektiv, som Götzsche og Kristensen anlægger. Kratschmers italiensk-enkeltsproglige (dog på ingen måde ateoretiske) orientering i dette bidrag peger nok på, at deduktive principper løbende skal revurderes i lyset af enkelsprogenes egne love. 
Det skal også fremhæves, at italiensk og dansk (sammen med engelsk) rent typologisk står hinanden nær, når det gælder kasusmorfologi. Begge sprog benytter kun morfologisk kasus ved pronominer, og begge sprog gør derfor i høj grad brug af perifrastiske præpositionalfraser, som - i intersproglig sammenligning - kan tilordnes kasusfunktioner. Nogle af Kratschmers resultater skulle på denne baggrund også kunne overføres til dansk.

Det er Kratschmers mål at kortlægge de semantiske forhold i konstruktioner med dativlignende (på tysk "dativogene", sml. Kratschmer, afsnit1) prædikater, dvs. prædikative valensudtryk, som tillader dativiske "objekter", uanset deres formale realisering som dativformer eller præpositionalgrupper. Disse valensforhold, som kan kræve morfologisk dativ, præpositionelt dativ eller kan tillade begge to, er ifølge Kratschmer knyttet til semantiske distinktioner, som hidtil har været ukendte.

Kratschmers analyse bygger på omfangsrigt materiale af autentisk karakter, både tekster skaffet fra søgemaskinen Google og tests med italienske native speakers. Karakteristisk for Kratschmers analyse af dativfunktioner er det modale aspekt (til modalitet se Engerer 2005), der, hvis man følger Kratschmer, i høj grad strukturer feltet omkring de italienske "dativbetydninger", herunder epistemiske dativlignende prædikater og prædikater med deontisk-aletisk modal betydning. En særskilt klasse af dativlignende udtryk er de italienske prædikater sembrare og parere, som hører til den teoretisk interessante gruppe af seem-prædikater (på tysk scheinen-prædikater), som på italiensk, ligesom i mange andre sprog, forekommer med forskellige, dativlignende komplementer og specielle konstruktioner som raising og small clause-konstruktioner.

Den afsluttende del af Kratschmers bidrag er en analyse af dativlignende prædikater, deres valens og grundlæggende semantiske distinktioner inden for polyfoniteoriens rammer (ScaPoLine - Théorie Scandinave de la Polyphonie Linguistique, se litteraturhenvisningerne i Kratschmer, dette bind). Efter en koncis opridsning af teoriens grundantagelser fremlægger Kratschmer sin analyse af "dativiske semantiske roller" i den polyfone teori.

Vi håber, at dette temanummer vil bidrage til at holde diskussionen om kasus, sætningsled og især semantiske roller i gang - og i betragtning af de mange 
modstridende holdninger, som kommer til udtryk mange steder i de enkelte bidrag, har vi en formodning om, at der vil være basis for en løbende debat også fremover.

Vi ønsker alle god fornøjelse med denne udgave af Tidsskrift for Sprogforskning.

\section{LITTERATUR}

Bresnan, Joan (2001), Lexical-functional syntax, Malden/Mass.: Blackwell.

Burkard, Thorsten (2003), "Die lateinische Grammatik im 18. und frühen 19. Jahrhundert", in: Kessler, Eckhard, Heinrich C. Kuhn (eds.) (2003), Germania latina - Latinitas teutonica. Politik, Wissenschaft, humanistische Kultur vom späten Mittelalter bis in unsere Zeit, Paderborn: Wilhelm Fink.

Dowty, David (1991), "Thematic Proto-Roles and Argument Selection", Language, 67/3 (1991), pp. 547-619.

Engerer, Volkmar (2005) (ed.), Modality. Linguistic, Philosophical and Logical Aspects of a Universal Category, Århus: Nord Grafisk (= Tidsskrift for Sprogforskning, 3/2 2005).

Fillmore, Charles (1966), "Toward a Modern Theory of Case", The O.S.U. project on linguistic analysis, Report \#13.1-24, Columbus: Ohio State University.

Gruber, Jeffrey (1965), Studies in Lexical Relations, Ph. D. dissertation, M.I.T. \& Indiana University Lingustics Club.

Høysgaard, Jens Pedersen (1752), Methodisk Forsøg til en Fuldstoendig Dansk Syntax, optrykt i: Bertelsen, Henrik (red.) (1923), Danske Grammatikere fra Midten af det syttende til Midten af det attende Aarhundrede, vol. 5, København: Gyldendalske Boghandel, Nordisk Forlag. Genoptrykt 1979, København: C. A. Reitzel.

Krahe, Hans (1970), Einleitung in das vergleichende Sprachstudium, Innsbruck: Universität Innsbruck (= Innsbrucker Beiträge zur Sprachwissenschaft).

Meier-Brügger, Michael, Matthias Fritz, Manfred Mayrhofer (2002), Indogermanische Sprachwissenschaft, Berlin: Walter de Gruyter.

Seuren, Pieter A.M. (1998), Western Linguistics - An Historical Introduction, Oxford: Blackwell.

Valin Jr., R. D. van (1999), "Functional Relations", in: Brown, Keith, Jim Miller (eds.) (1999), Concise Encyclopedia of Grammatical Categories, Amsterdam, New York: Elsevier, pp. 150-162.

Wackernagel, Jacob (1926), Vorlesungen über Syntax, Erste Reihe, Basel: Verlag Birkhäuser. 


\section{STEN VIKNER OG VOLKMAR ENGERER}

\section{NOTER}

1 I denne sammenhæng skal der i øvrigt også gøres opmærksom på, at kasus ikke er det eneste grammatiske redskab til signalering af sætningsled og semantisk rolle. Intonationen spiller ligeledes en stor rolle ligesom det enkelte sprogs grammatiske træk, som så at sige indirekte og sekundært kan signalere sætningsled og semantisk rolle. Vi tænker her fx på den tyske kongruens, hvor subjektet "som sidegevinst" markeres i tilfælde af person- og/eller numerusdistinktioner ved verbet. Funktionelt set er kasus sikkert det mest specialiserede redskab, men det er alligevel kun ét blandt flere sproglige midler til markering af sætningsled og semantisk rolle. 